\title{
PKP
}

\section{PUBLIC KNOWLEDGE PROJECT}

\section{Take control of your publishing}

PKP is a not-for-profit research and development team at Simon Fraser University in Vancouver, Canada, developing 100\% open source software publishing platforms since 1998

Download them, use them, modify them, share them. For free. Always.

\begin{tabular}{|c|c|c|c|}
\hline OJS & OMP & OCS & QHS \\
\hline $\begin{array}{l}\text { The world's most widely used open } \\
\text { source journal management and } \\
\text { publishing system, created to make } \\
\text { open access a viable option for } \\
\text { journals }\end{array}$ & $\begin{array}{l}\text { An online content and workflow } \\
\text { management system for peer- } \\
\text { reviewed scholarly } \\
\text { monographs, edited volumes, } \\
\text { and scholarly editions }\end{array}$ & $\begin{array}{l}\text { An online publishing tool that allows } \\
\text { you to host conference web sites for } \\
\text { you and your colleagues; manage } \\
\text { submissions, post conference } \\
\text { proceedings and papers in a } \\
\text { searchable format, and more }\end{array}$ & $\begin{array}{l}\text { A free metadata indexing system } \\
\text { allowing you to create a } \\
\text { searchable, online database of } \\
\text { the metadata from Open } \\
\text { Archives Initiative (OAI)- } \\
\text { compliant sources, such as sites } \\
\text { using OJS or OCS }\end{array}$ \\
\hline
\end{tabular}

\section{Research \\ Our active research agenda explores broader areas of scholarly communicatio and education, with projects that reflect our ongong work to mprove our sotware and contibute to enhancing the tech communication}

\section{PKP School}

Free, online, self-paced learning

Courses helping new publishers, editors,

and reviewers build their skills and

knowledge in using PKP software as well

as increasing the quality and effectiveness

of their publications

Developing Library Publishing Program

\section{OJS for Journal} Managers, Editors, or Reviewers

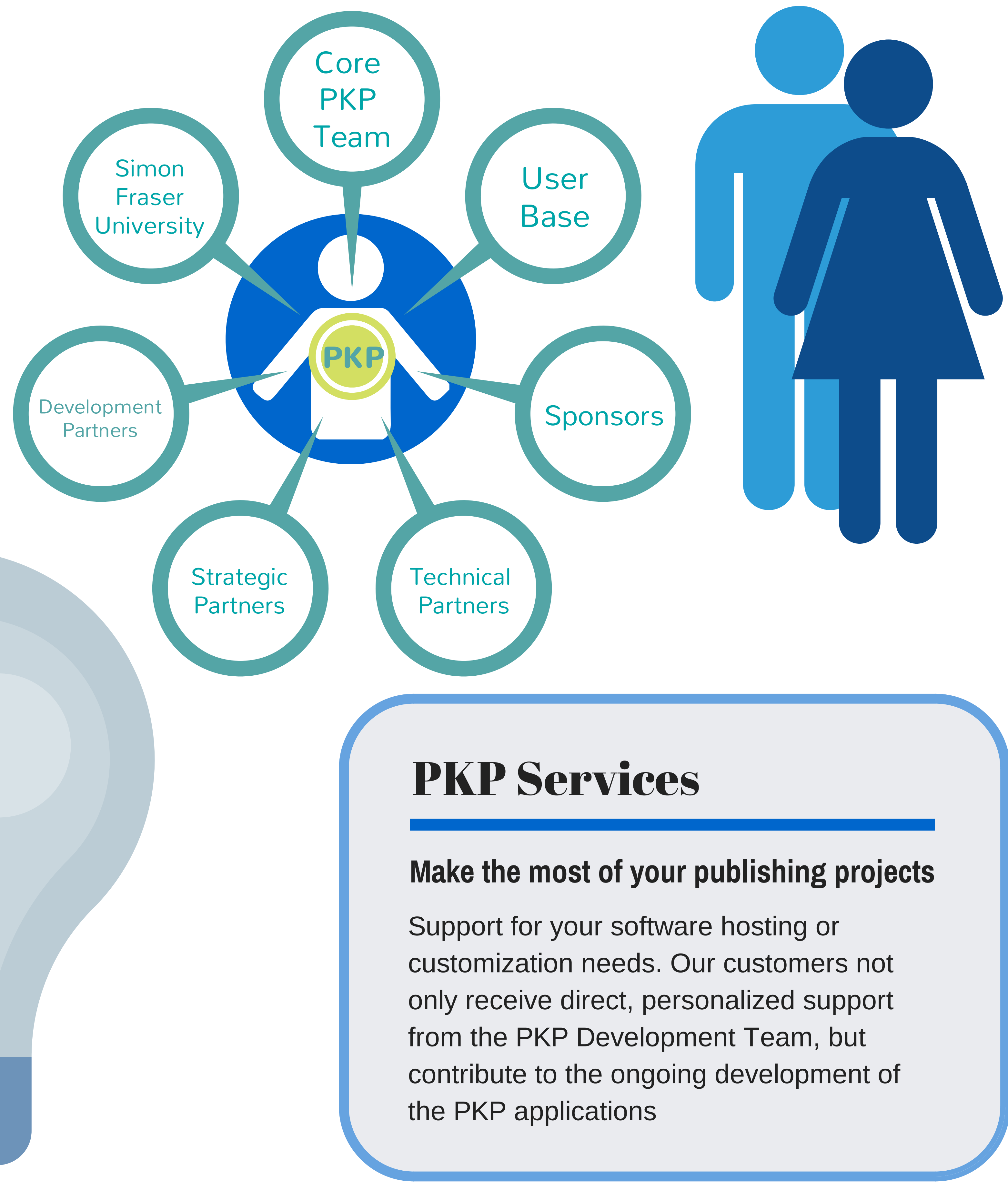

\section{PKP Sponsorships}

Building a strong publishing alternative Ask us how you can support Open Publishing!
The Challenge:

- Building a community of users around open source applications

- Establishing clear channels of communication between users, developers, and other stakeholders.

- Creating engagement and making sure that all voices are heard

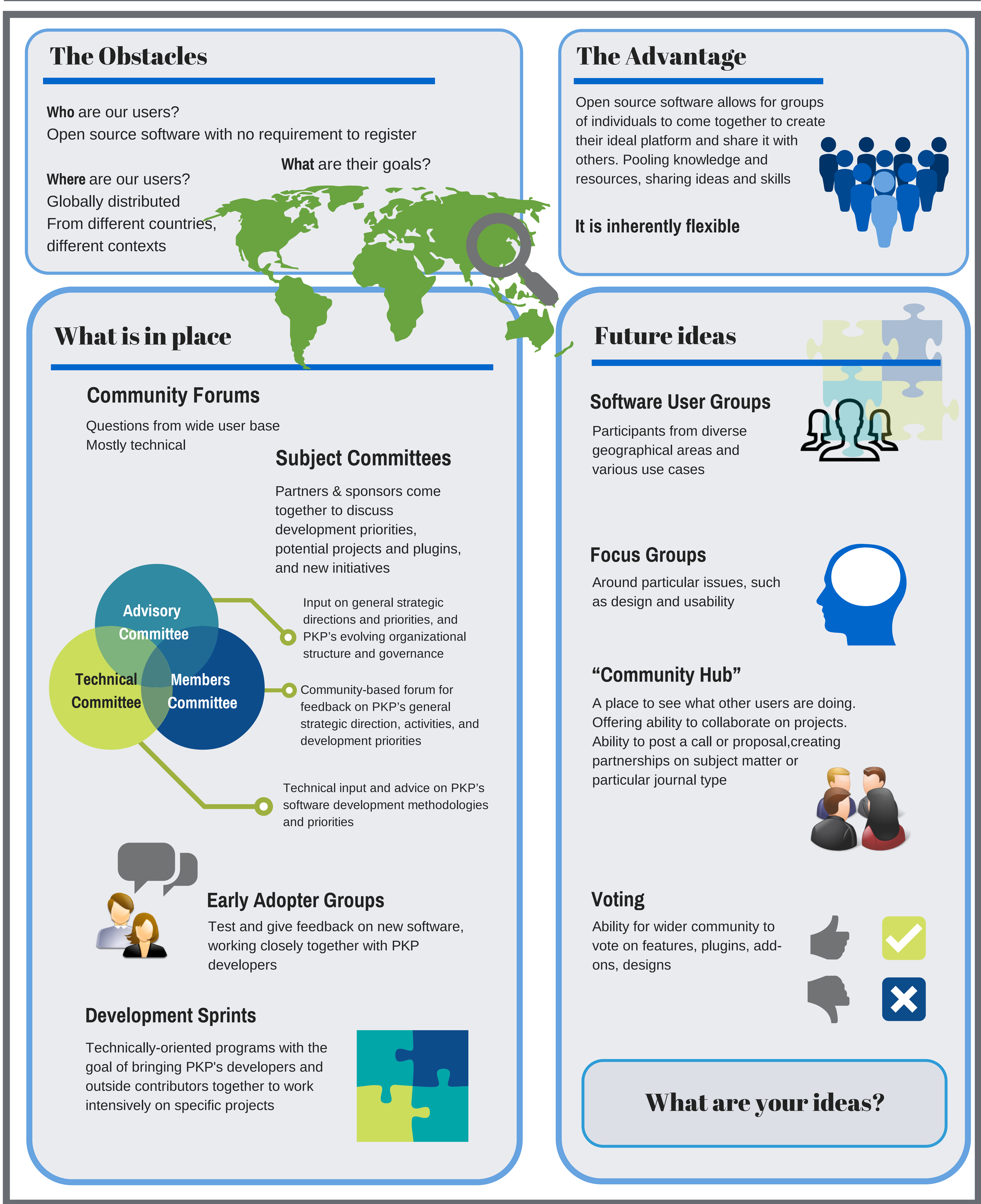

